\title{
Proteasomal activity in brain tissue following ischemic stroke in Wistar rats
}

\author{
O.I. Savchuk ${ }^{1}$, M.O. Orlovsky ${ }^{1}$, Ie.S. Iarmoliuk ${ }^{2}$, S.V. Goncharov ${ }^{1}$, V.E. Dosenko ${ }^{1}$, \\ G.G. Skibo ${ }^{1}$ \\ ${ }^{1}$ O.O. Bogomoletz Institute of Physiology of National Academy of Science of Ukraine, Kyiv; \\ ${ }^{2}$ O.O. Bogomolets National Medical University, Kyiv; e-mail: floweringbowl@ukr.net
}

Functional as well as structural reorganization of brain tissues takes place in the surrounding and remotes brain areas after focal ischemic lesions. In particular, reactive or regenerative processes have been described to occur in the infarction areas and the contralateral hemisphere. Experiments were performed on 63 rats, divided into 3 groups (each consisted of 21 animals): sham operated, short-term occlusion of the right middle cerebral artery (MCAO) group, and long-term MCAO group. We have studied changes in proteasome proteolysis during transient occlusion of the middle cerebral artery using method of Koizumi $J$., duration 2 and $60 \mathrm{~min}$ and made the comparison between changes in different types of proteasome activity and severity of ischemic injury and showed three types of decrease in proteolytic activity (trypsin-, chymotrypsin-like, peptidylglutamyl peptide-hydrolyzing) in the brain tissues. Chymotrypsin-like activity of ischemic areas of the brain for short-term MCAO decreased 4.1 times compared with controls (P>0.05), for long-term MCAO decreased 5.8 times compared with controls $(P<0.05)$. Trypsin-like activity of ischemic areas of brain for short-term MCAO decreased 7.1 times compared with controls $(P>0.05)$, for long-term $M C A O$ decreased 12.5 times compared with controls $(P<0.05)$. PGPH activity of ischemic areas for shortterm MCAO decreased 8 times compared with controls $(P>0.05)$, for long-term MCAO decreased 2.8 times compared with controls $(P<0.05)$. The similar dynamics was observed also in the penumbra and the core zone of the brain at $6 \mathrm{~h}$ of reperfusion, in the long run there is no significant difference between the core and contralateral zones. Our results suggest that proteasome activity may play also a role in contralateral cortical plasticity occurring after focal cerebral ischemia.

Key words: ischemic stroke; focal cerebral ischemia; proteasome.

\section{INTRODUCTION}

Ischemic stroke, occurring as a result of occlusion of major cerebral arteries, is a devastating disease, representing a leading cause of death and disability worldwide [1]. Brain ischemia, due to loss of cerebral blood flow, induces a complex interaction of several pathological perpetrators that eventually lead to cell death [2]. Despite recent advances, there are major gaps in our understanding of the pathogenesis of cerebral ischemic injury, and therapeutic options for stroke patients remain limited [3]. It is so necessary to study molecular mechanisms of this pathology, one of them is ubiquitinproteasome system which represents the main cellular pathway for protein degradation [4], contributing to important cellular processes, including transcriptional regulation, cognition, memory and other [5].

The accumulation of ubiquitin-containing protein aggregates following ischemia is a relatively unexplored research area that may provide new mechanistic insights into ischemic brain damage [6]. However, the factors leading to deposition of these aggregates and their consequences for stroke outcome are largely unknown and, as such, require additional elucidation.

Although the proteasome is responsible for the majority of intracellular protein degradation, and has been demonstrated to play a pivotal role in a diverse array of cellular activities, the role (C) O.I. Savchuk, M.O. Orlovsky, Ie.S. Iarmoliuk, S.V. Goncharov, V.E. Dosenko, G.G. Skibo 
of the proteasome in the central nervous system is only beginning to be elucidated [7]. The eukaryotic proteasome is a large multicatalytic, multisubunit protease complex possessing at least three distinct activities, which are associated with three different of subunits, respectively: chymotrypsin-like activity (with the B5 subunit), trypsin-like activity (with the B2 subunit), and peptidylglutamyl peptide-hydrolyzing (PGPH) activity (with the B1 subunit) [8].

Recent studies have demonstrated that proteasome inhibition occurs in numerous neurodegenerative conditions, and that proteasome inhibition is sufficient to induce neuron death, elevate intracellular levels of protein oxidation, and increase neural vulnerability to subsequent injury [9]. In other hand, proteasome inhibitors are very effective for prevantion of ischemic injury [10].

The aim of this investigation is to determine three types of proteasome activities in zone brain (core, penumbra, contralateral area) under shortterm and long-term carotid artery occlusion, compare infarction volume with behavioral tests in modelling of focal ischemic stroke.

\section{METHODS}

Adult male Wistar rats, weighing 280-320 g, were housed in standard cages with free access to food and water on a $12 \mathrm{~h}$ light/dark cycle. All procedures performed on animals were carried out in accordance with the Guide for the Care and Use of Laboratory Animals (National Research Council, 1996, USA) and were approved by the Animal Use and Care Committee of Bogomoletz Institute of Physiology National Academy of Science of Ukraine.

Sixty three rats were randomly allocated to one of three groups: sham group, short-term (MCAO) group, and long-term MCAO group. The rats in the sham group $(n=21)$ underwent right common carotid artery and external carotid exposure without MCAO, were anesthetized with calipsol $(75 \mathrm{mg} / \mathrm{kg})$ and xylazine $(10 \mathrm{mg} /$ $\mathrm{kg})$. In the short-term MCAO group $(\mathrm{n}=21)$, un- der the same anesthetic conditions and surgical procedures as sham group, the MCA was occluded for $2 \mathrm{~min}$. In long-term MCAO group ( $\mathrm{n}=$ 21), under the same anesthetic conditions and surgical procedures as sham group and shortterm MCAO group, the MCA was occluded for $60 \mathrm{~min}$. In all three groups reperfusion time was 6,24 and $72 \mathrm{~h}(\mathrm{n}=7)$. Animals were tested at 6 $\mathrm{h}, 24 \mathrm{~h}$ and $72 \mathrm{~h}$ to evaluate neurologic function [11]. At $6 \mathrm{~h}, 24 \mathrm{~h}$ and $72 \mathrm{~h}$ after reperfusion, a subset of the rats was sacrificed, and the brains were quickly harvested for the measurement of infarction ratio and proteasome activity.

Rectal temperature was monitored and kept at $37 \pm 0.5^{\circ} \mathrm{C}$ with a heating pad, and let temporalis muscle temperature was kept at 37.5 $\pm 0.2^{\circ} \mathrm{C}$ with a heating lamp. Focal cerebral ischemia was induced in rats by permanent occlusion of the right middle cerebral artery, using the suture method previously described, with modifications [11]. Briefly, the right common carotid artery was exposed, and the external carotid artery was isolated and coagulated. A 4-0 silicone-coated nylon suture (Doccol Co., Albuquerque, NM, USA) was inserted into the internal carotid artery through the external carotid artery stump and gently advanced to occlude the MCA. After completion of the proximal MCAO, the suture was gently withdrawn to permit reperfusion. The external carotid stump was ligated and the wound closed, and the rats were maintained under temperature control until they were returned to animal cages $1 \mathrm{~h}$ later.

\section{Infarction Volume Measurements}

The animals were sacrificed at 6,24 or $72 \mathrm{~h}$ after MCAO, after which the brains were rapidly removed and sectioned coronal at 2-mm intervals. Sections were taken from the region beginning $1 \mathrm{~mm}$ from the frontal pole and ending just rostral to the corticocerebellar junction and stained with 2\% 2,3,5-triphenyltetrazolim hydrochloride (TTC) ("Sigma", St. Louis, MO, USA), for $15 \mathrm{~min}$ at $37^{\circ} \mathrm{C}$. The infracted tissue remained white, whereas normal tissue was stained red. The lesion volume ( $\mathrm{mm} 3)$ was 
determined by multiplying the appropriate area by the section interval thickness. To reduce errors associated with processing of tissue for histological analysis, the ischemic volume is presented as the percentage of infarct volume of the contralateral hemisphere (indirect volume calculation). Infarct areas of all sections were added to derive the total infarct area, which was multiplied by the thickness of the brain sections to determine the infarct volume. To compensate for the effect of brain edema, the corrected percentage of infarction was calculated as follows: percentage of infarction $=$ [measured infarct area - (ipsilateral hemisphere area - contralateral hemisphere area)]/[(ipsilateral hemisphere area + contralateral hemisphere area) - (ipsilateral hemisphere area - contralateral hemisphere area)] [12].

MCAO in rats typically causes varying degrees of both somatosensory and motor impairment. Thus, it is important that evaluation of neurological function following experimental stroke consist of a battery of tests that evaluate the degree of sensory and motor impairment in an accurate, reproducible manner. A multitude of tests have been developed to evaluate these functions. A test such as the Open field has been proposed as test of motor function, while the Adhesive Removal (sticky-tape) test is often utilized as a test of somatosensory function. These tests were performed after $6,24,72 \mathrm{~h}$ of reperfusion at modeling ischemic brain damage.

\section{Proteasomal activity}

Brain samples (10\% wt/vol) were homogenized either in tris-HCl. The total brain homogenate was centrifuged at 5,000 $\mathrm{g}$ for five min, and the supernatants (cytosolic fractions) were used for the determination of protease alkaline and peptidase activities. The fluorogenic peptide substrate Suc-Leu-Leu-Val-Tyr-7-amydo-4-methylcoumarin (S6510; "Sigma-Aldrich") was used to measure the chymotrypsin-like activity of the proteasome, Boc-Leu-Ser-Thr-Arg-7-amydo4-methylcoumarin (B4636; "Sigma-Aldrich") was used for the trypsin-like activity and CBZ-
Leu-Leu-Glu-7-amydo-4-methylcoumarin (C0483; "Sigma-Aldrich") for the PGPH activity $[13,14]$. After a 30-min (for trypsin-like activity) or $1 \mathrm{~h}$ (for other activities) incubation with one of these fluorogenic peptides (at a concentration of $6 \mu \mathrm{M}$ ), fluorescence of the reaction products was monitored at $380 \mathrm{~nm}$ excitation and $440 \mathrm{~nm}$ emission using free 7-amino4-methylcoumarin as a standard on a Hitachi 4000 spectrofluorometer. The reactions were carried out in the absence or presence of selective proteasome inhibitors - clasto-lactacystin $\beta$-lactone $(2.5 \mu \mathrm{M})$ - to differentiate between nonproteasome- and proteasome-mediated peptide hydrolysis. The percentage of inhibition of respective substrate hydrolysis after treatment with a specific inhibitor was evaluated as the proteasome activity and was expressed as nanomoles per liter 7-amino-4-methylcoumarin per $10^{6}$ cells per $1 \mathrm{~min}$.

\section{Statistical analysis}

All values are presented as an arithmetic mean \pm standard error. Data in all groups was tested for normality of distribution using the one-sample Kolmogorov-Smirnov test, and the analysis of variance was performed using one-way ANOVA. Results were considered statistically significant at the $\mathrm{P}<0.05$ level. The software used was MS Excel 2007 and SPSS Statistics 17.0.

\section{RESULTS}

Infarction volume was then calculated by summing the infarction areas over all sections and multiplying by the slice thickness (table). Whereas no histological damage was noted in shamoperated rats, focal ischemia led to a brain lesion affecting the temporoparietal cortex, including mainly the primary somatosensory cortex. Brain damage also affected, but to a minor extent, a small part of the S1 forelimb cortex, a lateral portion of the primary motor cortex, the secondary somatosensory cortex, the agranular insular cortex, and the ectorhinal and auditory cortex. Furthermore, in some animals, 
Volume of ischemic brain areas $\left(\mathrm{mm}^{3}\right)$ in rats at different periods of reperfusion after $\operatorname{MCAO}(\mathrm{M} \pm \mathrm{m}, \mathrm{n}=\mathbf{1 4})$.

\begin{tabular}{|c|c|c|c|c|}
\hline \multicolumn{2}{|c|}{ Volume of ischemic brain areas } & $\begin{array}{c}\text { Infarct volume, } \mathrm{mm}^{3} \\
\text { (Total infarction) }\end{array}$ & Penumbra, $\mathrm{mm}^{3}$ & Core, $\mathrm{mm}^{3}$ \\
\hline \multirow{2}{*}{$6 \mathrm{~h}$} & short- term & $5.11 \pm 1.25$ & - & - \\
\cline { 2 - 5 } & long-term & $9.18 \pm 1.43^{*}$ & $7.24 \pm 1.13$ & $1.95 \pm 0.31$ \\
\hline \multirow{2}{*}{$24 \mathrm{~h}$} & short-term & $5.52 \pm 1.47$ & - & - \\
\cline { 2 - 5 } & long- term & $11.47 \pm 5.41^{*}$ & $5.16 \pm 2.43$ & $6.32 \pm 2.97$ \\
\hline \multirow{2}{*}{$72 \mathrm{~h}$} & short-term & $10.01 \pm 2.34$ & - & - \\
\cline { 2 - 5 } & long-term & $21.27 \pm 2.07^{*}$ & $2.77 \pm 0.27$ & $18.50 \pm 1.80$ \\
\hline
\end{tabular}

$* \mathrm{P}<0.05$.

an expansion of the lesion can be observed in white matter, as well as shrinkage of a small portion of the lateral striatum. The lesion volumes were $5.11 \pm 1.25 \mathrm{~mm}^{3}, 5.52 \pm 1.47,10.01 \pm 2.34$ in short-term MCAO group after $6,24,72 \mathrm{~h}$ respectively (histological measurements) and $9.18 \pm 1.43,11.47 \pm 5.41,21.27 \pm 2.07$ in long-term MCAO group after $6,24,72 \mathrm{~h}$ respectively (table $1, \mathrm{P}<0.05)$. According to the literature, on the 3rd day after MCAO the area of ischemic damage has clearly delineated, with perifocal edema zone is less expressed than on the 1st - 2nd day.

After the staining TTC there was revealed a significant prevalence of infarction volume areas in the long-term MCAO group with time of reperfusion $72 \mathrm{~h}-\left(21.27 \pm 2.07 \mathrm{~mm}^{3}\right)$ of the corresponding values in the other group of animals at the same time of reperfusion (shortterm MCAO - 10.01 $\pm 2.34 \mathrm{~mm}^{3}, \mathrm{P}<0.05$ ) (Fig. $1)$. Dimensions zone lesions in the long-term MCAO group with time of reperfusion $24 \mathrm{~h}$ $\left(11.47 \pm 5.41 \mathrm{~mm}^{3}\right)$ of the corresponding values in the other group of animals at the same time of reperfusion (short-term MCAO - 5.52 \pm 1.47 $\mathrm{mm}^{3}, \mathrm{P}<0.05$ ). Dimensions zone lesions in the long-term MCAO and the short-term MCAO were also statistically significant $(9.18 \pm 1.43$ $\mathrm{mm}^{3}$ and 5.11 \pm 1.25 , respectively, $\mathrm{P}<0.05$ ).

We measured three types of proteolytic activity of the proteasome (trypsin-, chymotrypsinlike and peptidylglutamyl peptide-hydrolyzinglike) in the brain tissues. Various activities of the proteasome activity vary in different directions. After $6 \mathrm{~h}$ of reperfusion in the core zone all kinds of proteasomal activity are activated comparable with the amplitude of short-term MCAO, in cases not only short-term MCAO but also with long-term MCAO, while in cases of large spread short-term MCAO. This activation was not statistically reliable, but for long-term MCAO - statistically significant (Fig. 2). Chymotrypsin-like activity of ischemic areas of the brain for short-term MCAO decreased 4.1 times compared with controls ( $\mathrm{P}>0.05)$, for long-term MCAO decreased 5.8 times compared with controls $(\mathrm{P}<0.05)$. Trypsin-like activity of ischemic areas of brain for short-term MCAO decreased 7.1 times compared with controls $(\mathrm{P}>0.05)$, for long-term MCAO decreased 12.5 times compared with controls $(\mathrm{P}<0.05)$. $\mathrm{PGPH}$ activity of ischemic areas for short-term MCAO decreased 8 times compared with controls $(\mathrm{P}>0.05)$, for long-term MCAO decreased 2.8 times compared with controls $(\mathrm{P}<0.05)$. The similar dynamics was observed also in the penumbra and the core zone of the brain at 6 hour of reperfusion, in

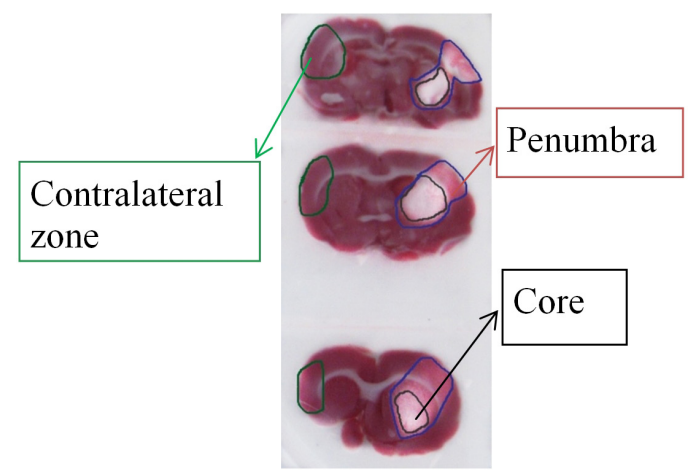

Fig. 1. Histological sections of brain after TTC staining 
the long run there is no significant difference between the core and contralateral zones. These data are summarized in Fig. 3.

Chymotrypsin-like activity of penumbra for short-term MCAO decreased 4.3 times compared with controls $(\mathrm{P}>0.05)$, for long-term MCAO decreased 11 times compared with controls $(\mathrm{P}>0.05)$. This activity of contralateral zone in
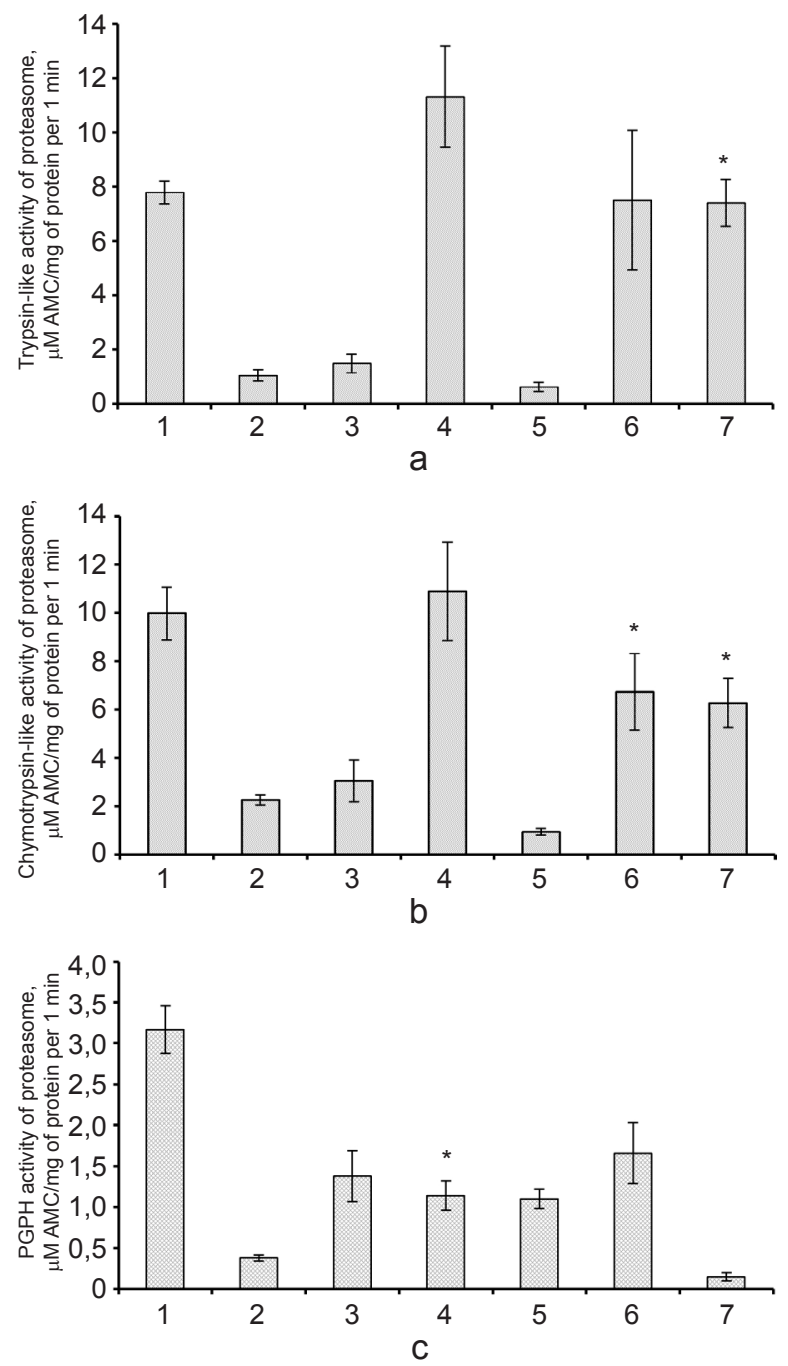

Fig. 2. Trypsin-like (a), chymotrypsin-like (b) and PGPH (c) activities of proteasome in core area of brain after MCAO. 1 - control; 2 - short-term MCAO group at $6 \mathrm{~h}$ period of reperfusion; 3 - short-term MCAO group at $24 \mathrm{~h}$ period of reperfusion; 4 - short-term MCAO group at $72 \mathrm{~h}$ period of reperfusion; 5 - long-term MCAO group at $6 \mathrm{~h}$ period of reperfusion; 6 - long-term MCAO group at $24 \mathrm{~h}$ period of reperfusion; 7 - long-term MCAO group at $72 \mathrm{~h}$ period of reperfusion. $\mathrm{N}=7 .{ }^{*} \mathrm{P}<0.05$ relation to damage zone for short-term MCAO decreased 4.3 times, for long-term MCAO decreased 3 times compared with controls $(\mathrm{P}<0.05)$. Trypsin-like activity of penumbra decreased 4.1 times compared with controls for short-term MCAO ( $\mathrm{P}>0.05)$, for long-term MCAO this type of activity decreased 25 times compared with controls $(\mathrm{P}>0.05)$ and decreased 4.1 times for contralateral zone in relation to damage zone for short-term MCAO, for long-
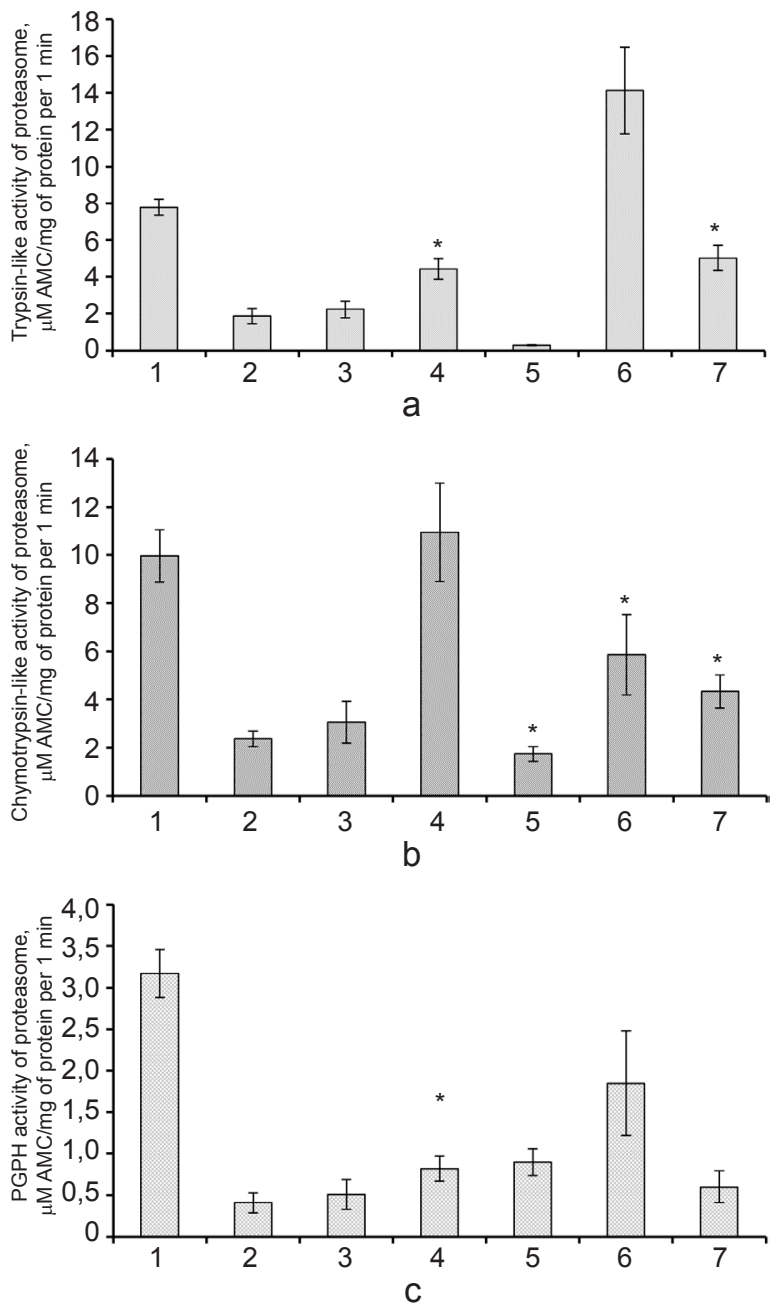

Fig. 3. Trypsin-like (a), chymotrypsin-like (b) and PGPH (c) activities of proteasome in penumbra after MCAO. 1 - control; 2 - short-term MCAO group at $6 \mathrm{~h}$ period of reperfusion; 3 - short-term MCAO group at $24 \mathrm{~h}$ period of reperfusion; 4 - short-term MCAO group at $72 \mathrm{~h}$ period of reperfusion; 5 - long-term MCAO group at $6 \mathrm{~h}$ period of reperfusion; 6-longterm MCAO group at $24 \mathrm{~h}$ period of reperfusion; 7 - long-term MCAO group at $72 \mathrm{~h}$ period of reperfusion. $\mathrm{N}=7 . * \mathrm{P}<0.05$ 
term MCAO it decreased 9 times compared with controls $(\mathrm{P}<0.05)$. PGPH activity of penumbra for short-term MCAO decreased 6.3 times for short-term MCAO compared with controls $(\mathrm{P}>0.05)$, for long-term MCAO it decreased 3.7 times compared with controls $(\mathrm{P}>0.05)$. This activity decreased 4.5 times for contralateral zone in relation to damage zone for short-term $\mathrm{MCAO}$, for long-term MCAO it decreased 2.5 times compared with controls $(\mathrm{P}<0.05)$. This suggests that the activation of the proteasome is a reactive processes rather than a mechanism of neuronal damage.

At $24 \mathrm{~h}$ of reperfusion there was a significant strengthening of trypsin-like both in the core zone and in the penumbra and this is observed only during long-term MCAO and at short-term MCAO such effects did not appear and also in contralateral is not observed (Fig. 2, a).

Trypsin-like activity decreased 7.1 times for core at $6 \mathrm{~h}$ of reperfusion for short-term MCAO compared with controls $(\mathrm{P}>0.05)$, for long-term MCAO it decreased 12.5 times compared with controls $(\mathrm{P}<0.05)$. This activity of penumbra for short-term MCAO decreased 4.1 times, for long-term $\mathrm{MCAO}$ it decreased 25 times compared with controls $(\mathrm{P}<0.05)$. Trypsin-like activity decreased 5.5 times for core at $24 \mathrm{~h}$ of reperfusion for short-term MCAO compared with controls $(\mathrm{P}>0.05)$, for long-term MCAO it decreased 1.1 time compared with controls $(\mathrm{P}<0.05)$. This activity decreased 4 times for penumbra at $24 \mathrm{~h}$ of reperfusion for short-term MCAO, for long-term MCAO it increased 1.8 times compared with controls $(\mathrm{P}<0.05)$. These processes which are related to damage and confirmed: "If ischemia is longer, the activation will be stronger". There is a clear dependence of the effect on the duration of ischemia. Short-term MCAO did not induce any significant changes in trypsin-like proteasome activity neither in core, nor penumbra regions.

In short-term MCAO the peak of activity was not at $24 \mathrm{~h}$ after reperfusion but on $72 \mathrm{~h}$. At that occurred reaction as chymotrypsin- and trypsinlike activity and this reaction was observed in the core and penumbra. Chymotrypsin-like activity decreased 4.1 times for ischemic areas for short-term MCAO at $6 \mathrm{~h}$ of reperfusion compared with controls $(\mathrm{P}>0.05)$, for penumbra it decreased 4.5 times compared with controls $(\mathrm{P}>0.05)$; at $24 \mathrm{~h}$ of reperfusion this activity decreased 3.8 times compared with controls for core zone $(\mathrm{P}>0.05)$ and for penumbra it decrease 3.2 times compared with controls $(\mathrm{P}>0.05)$; at 72 $\mathrm{h}$ of reperfusion this activity for core increased 1.1 times compared with controls $(\mathrm{P}>0.05)$ and for penumbra of this period it decrease 1.2 times compared with controls $(\mathrm{P}>0.05)$.

Trypsin-like activity decreased 7.1 times for ischemic areas of brain for short-term MCAO at $6 \mathrm{~h}$ of reperfusion compared with controls $(\mathrm{P}>0.05)$ and it decreased 11 times compared with controls for penumbra at this period $(\mathrm{P}>0.05)$; this activity decreased 5.5 times compared with controls at $24 \mathrm{~h}$ of reperfusion for core zone $(\mathrm{P}>0.05)$ and for penumbra of this period it decreased 1.4 times, at $72 \mathrm{~h}$ of reperfusion for core zone this activity increased 1.4 times compared with controls $(\mathrm{P}>0.05)$ and it decreased 1.5 times for penumbra.

In long-term MCAO the peak of activity was at $24 \mathrm{~h}$ but not at 72 . In some areas there are observed reduced activity. In case of longterm activation occurs earlier, that is logically.

Chymotrypsin-like activity decreased 5.5 times compared with controls for ischemic areas of the brain for long-term MCAO at $6 \mathrm{~h}$ of reperfusion $(\mathrm{P}<0.05)$, for penumbra it decreased 4.5 times compared with controls $(\mathrm{P}>0.05)$; this activity for core zone decreased 1.7 times compared with controls at $24 \mathrm{~h}$ of reperfusion $(\mathrm{P}<0.05)$ and it decreased 1.4 times compared with controls for penumbra $(\mathrm{P}>0.05)$; at $72 \mathrm{~h}$ of reperfusion this activity for core zone increased 2.2 times compared with controls $(\mathrm{P}>0.05)$ and for penumbra of this period it decrease 1.5 times compared with controls ( $\mathrm{P}>0.05)$ (Fig. 3, b).

Trypsin-like activity decreased 12.5 times compared with controls for ischemic areas of brain for long-term MCAO at $6 \mathrm{~h}$ of reperfusion $(\mathrm{P}<0.05)$ and it decreased 25 times com- 
pared with controls for penumbra at this period $(\mathrm{P}<0.05)$; at $24 \mathrm{~h}$ of reperfusion for core zone this activity decreased 1.1 time compared with controls $(\mathrm{P}>0.05)$ and for penumbra of this period it increased 1.8 times, at $72 \mathrm{~h}$ of reperfusion for core zone this activity decreased 1.1 time compared with controls $(\mathrm{P}>0.05)$ and it decreased 1.4 times for penumbra $(\mathrm{P}>0.05)$.

We should also note that pattern activation of PGPH in core is not strongly differ and is almost the same with all types of proteasome activity (Fig. 2, c). PGPH activity decreased 6.2 times compared with controls for core zone for short-term MCAO at 6 h of reperfusion $(\mathrm{P}>0.05)$ and for long-term MCAO it decrease 2.7 times compared with controls $(\mathrm{P}<0.05)$; this activity of core zone for short-term MCAO decrease 2.3 times compared with controls at $24 \mathrm{~h}$ of reperfusion $(\mathrm{P}>0.05)$ and for long-term $\mathrm{MCAO}$ it decreased 1.9 times compared with controls $(\mathrm{P}>0.05)$; this activity decreased 2.7 times compared with controls at $72 \mathrm{~h}$ of reperfusion of core zone or short-term MCAO $(\mathrm{P}>0.05)$ and for long-term MCAO of this period it decreased 20 times compared with controls $(\mathrm{P}>0.05)$.

Chymotrypsin and trypsin-like activities increase in contralateral area at the period of $72 \mathrm{~h}$ reperfusion (Fig. 4). In this case activation was not occurred in group of Long-term MCAO and Short-term MCAO and this activation was not connected with damage of neurons because this is contralateral hemisphere. Activation on this area was not occurred at 24, but at 72 in central zone. This reaction was reactive and more marked for Short-term MCAO than for long-term MCAO. And it distinguishes reaction in contralateral zone between core zones.

\section{DISCUSSION}

We have studied changes in proteasome proteolysis during transient occlusion of the middle cerebral artery using method of Koizumi J., duration 2 and $60 \mathrm{~min}$ and made the comparison between changes in different types of proteasome activity and severity of ischemic injury and showed three types of decrease in proteolytic activity (trypsin-like, chymotrypsin-like, PGPH) in the brain tissues.

We have also received data that with increasing time of ischemia, the necrosis size is increased and obtained correlation of these data with behavioral tests that confirm the response to stress or injury. It has been intensively studied because delayed neuronal death provides a window of opportunity for studying ongoing
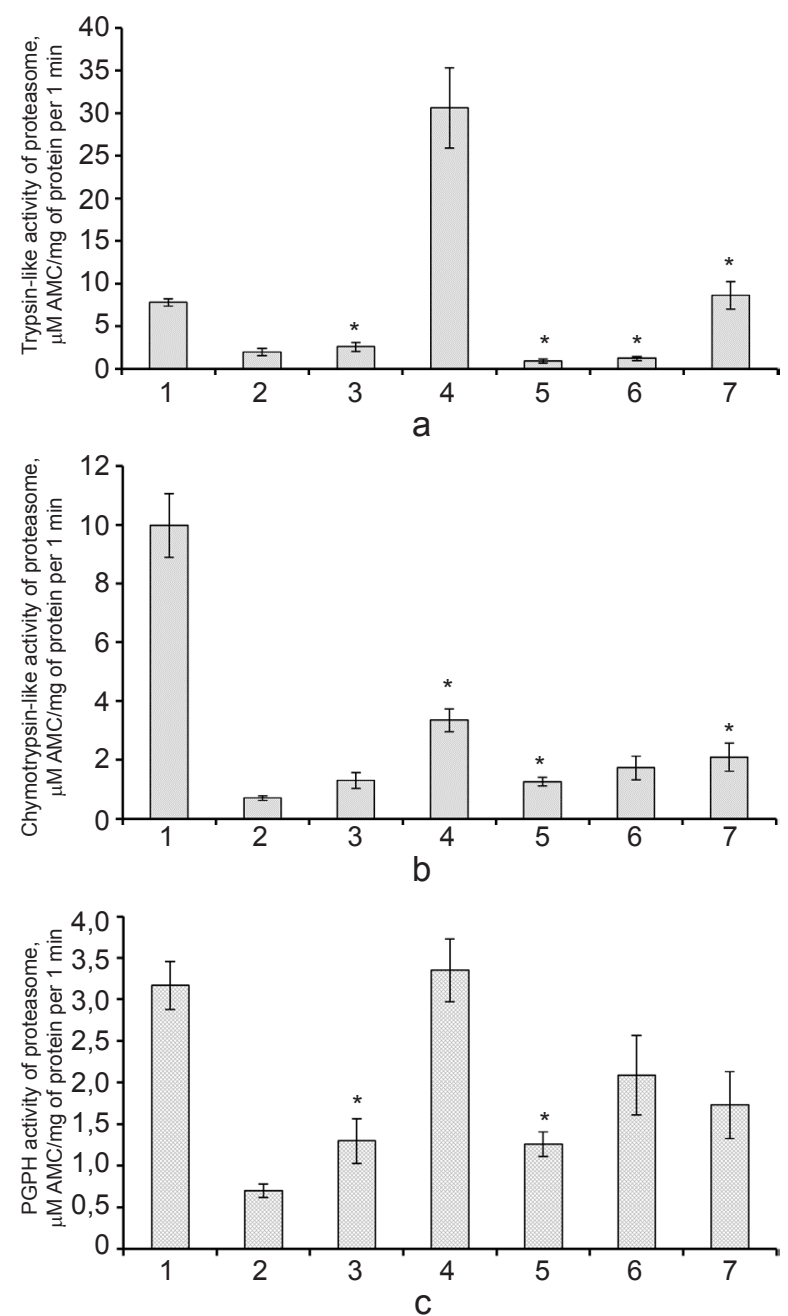

Fig. 4. Trypsin-like (a), chymotrypsin-like (b) and PGPH (c) activities of proteasome in contralateral area after MCAO. 1 - control; 2 - short-term MCAO group at $6 \mathrm{~h}$ period of reperfusion; 3 - short-term MCAO group at $24 \mathrm{~h}$ period of reperfusion; 4 - short-term MCAO group at $72 \mathrm{~h}$ period of reperfusion; 5 - long-term MCAO group at $6 \mathrm{~h}$ period of reperfusion; 6- long-term MCAO group at $24 \mathrm{~h}$ period of reperfusion; 7 - long-term MCAO group at $72 \mathrm{~h}$ period of reperfusion. $\mathrm{N}=7$. ${ }^{*} \mathrm{P}<0.05$ 
molecular processes before neuronal death after brain ischemia [15].

Intracellular proteolysis of proteasome activity significantly decreased in brain tissues in modeling transient occlusion of the middle cerebral artery and may have pathogenetic significance. What is the nature - or actually pathological adaptation is a change of proteasome activity in brain tissues during ischemia will determine further stages of proteasome inhibitors.

The current study demonstrates that proteasome activity is decreased after IRI (ischemic reperfusion injury) and may therefore contribute to neuronal injury during IRI. For example, inhibition of the proteasome is sufficient to induce neuron death [16]. In addition to directly inducing neuron death, subtoxic levels of proteasome inhibition would be expected to increase neuronal viability. Proteasome activity is required for most forms of NFkB activation [17], a transcription factor which has been demonstrated to have neuroprotective properties in vitro and in vivo. Because the proteasome is responsible for the removal of damaged and oxidized proteins [18], impaired proteasome activity may contribute to oxidative stress during IRI. It is interesting to speculate that the increase in proteasome activity in the contralateral hemisphere, which did not undergo significant increases in neuron damage after IRI in the current study, may represent a neuroprotective activation of proteasome activity. Alternatively, low levels of oxidative stress have been demonstrated to stimulate proteasome activity [18] and may account for increases in proteasome activity within the contralateral hemisphere.

All three types of proteasome activities were changed in the aorta, heart tissues, and blood leucocytes in modeling of cholesterol atherosclerosis [14]. The chymotrypsin-, trypsin-like, and PGPH activities of the proteasome occur at distinctive sites within the proteasome. The proteasome degrades substrates in a processive fashion that is believed to be particuarly important for preventing the accumulation of partially degraded proteins and the partial degradation of a substrate, which may allow for its contin- ued functioning. For example, by degrading a regulatory portion, but not the active enzymatic portion of a proteasome substrate, the activity of that substrate could continue to aberrantly function. Alternatively, proteasome inhibition could increase the half-life of proapoptotic proteins within neurons, increasing the toxicity of their activation. It is interesting to point out that pharmacologic inhibition of the proteasome is sufficient to induce caspase activation, which may be due in part to the decreased catabolism of activated caspases (data not shown). Adjusted changes of ubiquitin-proteasome system to sschemia in the postischemic hippocampus, conjugated ubiquitin (Ub) accumulates and free $\mathrm{Ub}$ is depleted. The accumulation of conjugated Ub may reflect hypofunction of downstream proteasome activity that normally degrades ubiquitinated proteins. Moreover, direct injection of a proteasome inhibitor into the lateral ventricles of the rat-induced DNA fragmentation in various CNS areas, suggesting that suppression of proteasome is able to induce neuronal apoptosis [19].

Therefore, it is reasonable to speculate that proteasome malfunction may in part underlie the molecular events of the ischemia-induced neuronal death. Decreased proteasome activity at the ischemic core and the surrounding tissues allows accumulation of oxidized proteins, resulting in formation of protein aggregates, ER stress, impairment of cell function, and eventually cell death. In an experimental ischemia of rat brains, a $60 \%$ elevation of Ub conjugate levels in the ischemic compared with the nonischemic animals was observed within 1 hour of recovery. The conjugate immunoreactivity remained at this level for $6 \mathrm{~h}$ but eventually decreased to control levels by $24, \mathrm{~h}$ of recovery. Increased formation of poly-Ub conjugates was accompanied with a significant increase in the transcription levels of poly-Ub genes [20].

It is likely that the loss of proteasome activity occurs in other age-related neurodegenerative disorders that exhibit increased oxidative damage, including Parkinson's disease and Huntington's disease. It will be important to determine 
which environmental and genetic stimuli in each of these disorders mediate decreased proteasome activity.

Numerous studies now clearly demonstrate that inhibition of the proteasome is sufficient to induce cell death in both neuronal and glial cells. These studies have demonstrated that proteasome inhibitors can induce several hallmarks of apoptosis, including caspase activation, cytochrome $\mathrm{C}$ release, elevated $\mathrm{p} 53$ expression, chromatin fragmentation, and DNA laddering $[13,18]$. Recent studies have demonstrated that proteasome inhibition may occur in a wide array of neurodegenerative disorders, including ischemia-reperfusion injury [5], Alzheimer's disease [21], and Parkinson's disease [22]. In each of these conditions, the ability of proteasomes to generate neuorogenic substrates from peptides specific for individual proteasome activities has been demonstrated. It is important to point out that while these peptides can be extremely useful as a determinant of proteasome activity, they may not fully account for functional impairments in proteasome activity. For example, the ability to cleave a chymotrypsin-like substrate may be only slightly inhibited in a particular tissue, even though the ability of the proteasome to degrade a specific protein may be severely inhibited [23].

The ability of proteasome inhibition to induce such a wide variety of cell death events suggests that proteasome activity plays a critical role in multiple aspects of neuronal homeostasis.

\section{О.І. Савчук, М.О. Орловський, Є.С. Ярмолюк, С.В. Гончаров, В.С. Досенко, Г.Г. Скибо \\ АКТИВНІСТЬ ПРОТЕАСОМИ В ТКАНИНАХ ГОЛОВНОГО МОЗКУ ЩУРІВ ЛІНІЇ ВІСТАР ПІСЛЯ ІШЕМІЧНОГО ІНСУЛЬТУ}

Моделювання ішемічного ушкодження головного мозку спричинює функціональні та структурні зміни його будови. Зокрема, були описані активні або регенеративні процеси, що відбувалися в зонах інфаркту та контралатеральній півкулі. Дослідження проведено на 63 щурах, розподілених на 3 експериментальні групи (по 21 тварині у кожній): група тварин 3 короткотривалою оклюзією середньої мозкової артерії (ОСМА), група з довготривалою ОСМА та тварин з удаваною операцією. Визначено зміни трьох видів протеасомної активності в тканинах головного мозку при моделюванні ішемічного пошкодження за допомогою транзиторної оклюзії середньої мозкової артерії за методикою Koizumi J., та співав., що тривала 2 і 60 хв та проведено порівняння між змінами різних видів протеасомної активності і ступенем ушкодження головного мозку щурів. Було виявлено зниження трьох видів (трипсино-, хімотрипсиноподібної та пептидилглутамілпептидгідролазної) протеолітичної активності в тканини головного мозку. Хімотрипсиноподібна активність ішемічної ділянки мозку при короткостроковій ОСМА знизилася в 4,1 раза ( $\mathrm{P}>0,05)$, при довгостроковій в 5,8 раза порівняно 3 контролем $(\mathrm{P}<0,05)$. Трипсиноподібна активність ішемічної зони мозку при короткостроковій ОСМА знизилася в 7,1 раза $(\mathrm{P}>0,05)$, при довгостроковій в 12,5 раза порівняно 3 контролем $(\mathrm{P}<0,05)$. Пептидилглутамілпептидгідролазна активність ішемічної ділянки при короткостроковій ОСМА зменшилася в 8 разів $(\mathrm{P}>0,05)$, при довгостроковій в 2,8 раза в порівнянні 3 контролем $(\mathrm{P}<0,05)$. Подібна динаміка спостерігалася також в зоні напівтіні й ішемічній ділянках мозку при 60 хв реперфузії. в довгостроковій перспективі не відмічається істотної різниці між ішемічною ділянкою та контралатеральною зоною. Отримані результати свідчать про те, що активність протеасоми може відігравати важливу роль у контралатеральній кортикальній пластичності після моделювання OCMA.

Ключові слова: ішемічний інсульт; фокальна ішемія; протеасома.

\section{Е.И. Савчук, М.А. Орловский, Е.С. Ярмолюк, С.В. Гончаров, В.Е. Досенко, Г.Г. Скибо}

АКТИВНОСТЬ ПРОТЕАСОМЫ В ТКАНИ ГО-
ЛОВНОГО МОЗГА КРЫС ЛИНИИ ВИСТАР
ПОСЛЕ ИШЕМИЧЕСКОГО ИНСУЛЬТА

Моделирование ишемического повреждения головного мозга вызывает функциональные и структурные изменения его строения. В частности, были описаны активные или регенеративные процессы, происходившие в зонах инфаркта и контралатеральном полушарии. Исследование проведено на 63 крысах, распределенных на 3 экспериментальные группы (по 21 животных в каждой): группа животных с кратковременной окклюзии средней мозговой артерии (ОСМА), группа животных с долговременной ОСМА и животные с ложной операцией. Определены изменения трех видов протеасомной активности в тканях головного мозга при моделировании ишемического повреждения мозга путем транзиторной окклюзии средней мозговой артерии по методике Koizumi J., и соавт.), которое длилось 2 и 60 мин и проведено сравнение между изменениями различных видов протеасомной активности и степенью повреждения головного мозга крыс. Было выявлено снижение трех видов (трипсино-, химотрипсиноподобной и пеп- 
тидилглутамилпептидгидролазной) протеолитической активности в тканях головного мозга. Химотрипсиноподобная активность ишемического участка мозга при краткосрочной ОСМА снизилась в 4,1 раза $(\mathrm{P}>0,05)$, при долгосрочной в 5,8 раза по сравнению с контролем $(\mathrm{P}<0,05)$. Трипсиноподобная активность ишемической зоны мозга при краткосрочной ОСМА снизилась в 7,1 раза ( $\mathrm{P}>0,05)$, при долгосрочной в 12,5 раза по сравнению с контролем $(\mathrm{P}<0,05)$. Пептидилглутамилпептидгидролазная активность ишемического участка при краткосрочной ОСМА уменьшилась в 8 раз (Р>0,05), при долгосрочной в 2,8 раза по сравнению с контролем $(\mathrm{P}<0,05)$. Подобная динамика наблюдалась также в зоне полутени и ишемических участках мозга при 60 мин реперфузии. В долгосрочной перспективе не отмечается существенной разницы между ишемическим участком и контралатеральной зоной. Полученные результаты свидетельствуют о том, что активность протеасомы может играть важную роль в контралатеральной кортикальной пластичности после моделирования ОСМА.

Ключевые слова: ишемический инсульт; фокальная ишемия; протеасома.

\section{REFERENCES}

1. Roger VL, Go AS, Lloyd-Jones DM, Benjamin EJ, Berry JD, Borden WB. Heart disease and stroke statistics-2012 update: a report from the American Heart Association. Circulation. 2012;125:2-220.

2. Britton P, Lu X-C, Laskosky M, Tortella FC. Dextromethorphan protects against cerebral injury following transient, but not permanent, focal ischemia in rats. Life Sci. 1997;60:1729-40.

3. Bulteau AL, Lundberg KC, Humphries KM. Oxidative modification and inactivation of the proteasome during coronary occlusion/reperfusion. 2001;276:30057-63.

4. Phillips JB, Williams AJ, Adams J, Elliott PJ, Tortella FC. Proteasome inhibitor PS519 reduces infarction and attenuates leukocyte infiltration in a rat model of focal cerebral ischemia. Stroke. 2000;31:1686-93.

5. Moskowitz MA, Lo EH, Iadecola C. The science of stroke: mechanisms in search of treatments. Neuron. 2010;67:181-98.

6. Ge P, Luo Y, Liu CL, Hu B. Protein aggregation and proteasome dysfunction after brain ischemia. Stroke. 2007;38:3230-6.

7. Ross CA, Poirier MA. Protein aggregation and neurodegenerative disease. Nat Med 2004;10:10-17.

8. Orlowski M, Wilk S. Catalytic activities of the $20 \mathrm{~S}$ proteasome, a multicatalytic proteinase complex. Arch Biochem Biophys. 2000;383:1-16.

9. Ross CA, Poirier MA. Opinion: What is the role of protein aggregation in neurodegeneration? Mol. Cell Biol. 2005;6:891-8.

10. Phillips JB, Williams AJ, Adams J, Elliott PJ, Tortella
FC. Proteasome inhibitor PS519 reduces infarction and attenuates leukocyte infiltration in a rat model of focal cerebral ischemia. Stroke. 2000;31:1686-93.

11. Koizumi J, Yoshida Y, Nakazawa T, Ooneda G. Experimental studies of ischcmic brain edema. A new experimental model of cerebral embolism in rats in which recirculation can be introduced in the ischemic area. Stroke. 1986;8:1-8.

12. Iarmoliuk IeS. Dynamics of functional disorders in different variants of tissue transplantation to activate angiogenesis on the models of focal cerebral ischemia in rats. $\mathrm{Ukr}$ NMM Zh. 2014;82(3):123-8. [Ukrainian].

13. Dosenko VE, Zagoriǔ VIu, Moĭbenko AA. Effect of proteasomal proteolysis on NO-synthase activity in isolated platelets. Ukr Biokhim Zh. 2005;77:39-43.

14. Pashevin DO, Dosenko VE, Byts IuV, Moibenko OO: Proteasome activity changes in the aorta, heart tissues, and blood leucocytes in modelling of cholesterol atherosclerosis. Fiziol Zh. 2007;53:3-10. [Ukrainian].

15. Tsymbalyuk VI, Iarmoliuk IeS. A modified model of experimental ischemic stroke in rats using silicone coating monofilaments. Ukr Nevrolog Zh. 2012; 4:97-105. [Ukrainian].

16. Qiu JH, Asai A, Chi S. Proteasome inhibitors induce cytochrome C-caspase-3-like protease-mediated apoptosis in cultured cortical neurons. J Neurosci. 2000;20(1):259-70.

17. Hershko A, Heller H, Elias S, Ciechanover A. Components of ubiquitinprotein ligase system. Resolution, affinity purification, and role in protein breakdown. J Biol Chem. 1983;258: 8206-14.

18. Ding Q, Dimayuga E, Martin S. Characterisation of chronic low-level proteasome inhibition on neural homeostasis. Neurochem. 2003;86:489-97.

19. Taglialatela G, Kaufmann JA, Trevino A, Perez-Polo JR. Central nervous system DNA fragmentation induced by the inhibition of nuclear factor Brit Neuroreport. 1998;9:489-93.

20. Keller JN, Huang FF, Zhu H, Yu J, Ho YS, Kindy TS. Oxidative stress-associated impairment of proteasome activity during ischemia reperfusion injury. J Cereb Blood Flow Metab. 2000;20:1467-73.

21. Hensley K, Hall N, Subramaniam R, Cole P, Harris M, Aksenov M, Aksenova M, Gabbita SP, Wu JF, Carney JM, Markesbery WR, Butterfield DA. Brain regional correspondence between Alzheimer's disease histopathology and biomarkers of protein oxidation. J Neurochem. 1995;65:2146-56.

22. Cardozo C., Michaud C. Proteasome-mediated degradation of tau proteins occur independently of the chymotrypsinlike activity by a nonprocessive pathway. Arch Biochem Biophys. 2002;408(1):103-10.

23. Ciechanover A. The ubiquitin-proteasome proteolytic pathway. Cell. 1994;79:13-21. 